IZA DP No. 5732

Roma Women in Athenian Firms:

Do They Face Wage Bias?

Nick Drydakis

May 2011 


\title{
Roma Women in Athenian Firms: Do They Face Wage Bias?
}

\author{
Nick Drydakis \\ University of Patras, \\ Scientific Centre for the Study of Discrimination, Athens \\ and IZA
}

\section{Discussion Paper No. 5732 \\ May 2011}

IZA

P.O. Box 7240

53072 Bonn

Germany

Phone: +49-228-3894-0

Fax: +49-228-3894-180

E-mail: iza@iza.org

Any opinions expressed here are those of the author(s) and not those of IZA. Research published in this series may include views on policy, but the institute itself takes no institutional policy positions.

The Institute for the Study of Labor (IZA) in Bonn is a local and virtual international research center and a place of communication between science, politics and business. IZA is an independent nonprofit organization supported by Deutsche Post Foundation. The center is associated with the University of Bonn and offers a stimulating research environment through its international network, workshops and conferences, data service, project support, research visits and doctoral program. IZA engages in (i) original and internationally competitive research in all fields of labor economics, (ii) development of policy concepts, and (iii) dissemination of research results and concepts to the interested public.

IZA Discussion Papers often represent preliminary work and are circulated to encourage discussion. Citation of such a paper should account for its provisional character. A revised version may be available directly from the author. 
IZA Discussion Paper No. 5732

May 2011

\section{ABSTRACT \\ Roma Women in Athenian Firms: Do They Face Wage Bias?}

In the current study, we analyze the effect of having a Roma background on women's wages. By utilizing the Athens Area Study random sample (2007-08) drawn from 16 multiethnic municipalities in which Roma live, we estimate that $66.1 \%$ of the wage differential between Roma and non-Roma female workers cannot be explained by differences in observed characteristics. Prejudices against Roma women are discussed and appear to explain the wage gap found here. The occupational segregation of the Roma in low-paid jobs and employers' statistical motivations are also found to influence wages earned by Roma. This study concludes that there is a need for better implementations of existing laws, rules and regulations which would counter the discrimination of minority women in the labor market. In addition, a better means of assessing workers' skill may contribute to the reduction of wage discrimination, as well as, greater educational achievement would significantly boost the economic status of Roma women. In its use of a random Roma sample and multivariate analysis, this study is a methodological advancement over previous studies of Roma employment, and it could inspire new efforts to compare wages by Roma background.

JEL Classification: J31, J71, J15, C13, C81

Keywords: Roma, labor discrimination, Blinder-Oaxaca decomposition, taste theory, statistical theory, occupational segregation

Corresponding author:

Nick Drydakis

Department of Economics

University of Patras

University Campus

26504 Rio

Greece

E-mail: ndrydakis@econ.soc.uoc.gr 


\section{Introduction}

The socio-economic surveys that have been conducted in Greece generally suffer from a lack of focus on issues concerning the status of minority women. Roma ${ }^{1}$ women in particular are invisible both in labor data collection and in employment research, resulting in an incomplete picture of their true condition and specific needs. In the current study, we are interested in examining the employment of Roma women in Athenian firms. As long as Roma women are a visible part of the country’s capital, many questions are raised. Where do Roma women work? Do they face wage differences after considering productive differences? The current study aims to answer some of these questions. Data pooled from a 2007-08 random sample, the Athens Area Study, which took place in the 16 Athenian multiethnic municipalities in which Roma population concentrate, allow the multivariate testing of whether the Roma face lower wages. In this study, to determine whether there are wage gaps against Roma workers, the process compares the wages of Roma workers to the wages of non-Roma workers. If Roma earn less than non-Roma, after accounting for differences in productivity, then the unexplained differential can be also attributed to labor market discrimination by employers.

\footnotetext{
${ }^{1}$ Roma are members of a social group sharing certain common ethnic, linguistic, and cultural characteristics that may differ according to their tribe or clan (Stewart, 1997). The term "Roma” is an endonym and refers to persons describing themselves as Roma, Gypsies, Manouches, Kalderash, Machavaya, Lovari, Churari, Romanichal, Gitanoes, Kalo, Sinti, Rudari, Boyash, Travellers, Ungaritza, Luri, Bashalde, Romungro, Yenish, Xoraxai, and other groups perceived as Gypsies (see European Monitoring Centre on Racism and Xenophobia, 2006). The term Roma is used in this study as shorthand, as adopted in reports from the European Commission and United Nations, and this practice is not intended to downplay the diversity within these communities or to promote negative stereotypes.
} 
Arguably, the most fundamental change in the European Union related to combating discrimination has been the adoption of a series of equality ordinances. The European Union has developed antidiscrimination legislation, which has been furthered by the recent transposition of the Race Equality Directive (2000/43) and the Employment Equality Directive (2000/78). Currently, the freedom of individuals belonging to ethnic and race minorities to express and celebrate their identities as members of such minorities has been recognized as an integral feature of the international protection of human rights. However, Eurofound (2010) suggests that, the persistence of the wage and promotion gap against minority women despite these legal changes still prompt concern about the equity or fairness of the market's setting process.

The existing evidence suggests that ethnic minority and especially Roma women are the most vulnerable to multiple discrimination and present higher risks of social exclusion and poverty than the women of the native population and minority men especially in accessing employment, education, health and social services (European Commission, 2008). In the view of these patterns, it is crucial to have demographics and employment analysis for Roma women for current evaluations and future comparisons in order to assert Roma women rights for better living conditions and to mobilize people around the rights of the Roma people. Moreover, as some studies suggest there to be a shift in gender relations in Roma families, brought about by women who either contribute to the household earnings (see, Jones' analysis, 1998) or are the main breadwinners of their families (see, the European Women's Lobby study, 1999 and European Commission, 2008) the examination of women's terms of employment and wage patterns is of much more interest. Also, the additional effect that having a Roma background has on females' lives is of great concern and needs evaluating. Indeed, in the view of black, immigrant, and disabled women's studies estimating the wage differential these people face, the aim of this study is to isolate the Roma effect on wages and 
offer a comparison with non-Roma women. Social scientists should place an emphasis on the complex relationship between different types of inequalities, as they are concerned with not only gender relations but also the role of other types of social relations in the determination of economic outcomes. Provided that identifying the sources of racial differences in wages is crucial in implementing effective policy decisions so as to reduce them.

Building on the lack of similar previous socio-economic studies, this analysis aims to achieve two primary goals. The first contribution of the study is theoretical. Roma discrimination has not been the subject of theoretical consideration in socio-economics. In this study we evaluate the three strands of the theoretical economic literature on discrimination in the context of race and ethnicity that can be extended into the realm of concern: Roma discrimination. Specifically, we focus on the Taste Theory (Becker, 1957; 1993), the Statistical Theory (Arrow, 1973; 1998), and the Segregation Theory (Bergmann, 1971; 1986; 1996) to integrate and synthesize the alternative motivations that can be used to evaluate wage differentials against Roma workers in the labor market. Second, we try to solidify our understanding of the statistical facts regarding the co-movement of individual wages and Roma origin using well-established techniques (Blinder-Oaxaca decomposition). Here, in order to examine the alternative theoretical explanations of wage discrimination, we focus on various occupation/sector and education level subgroups. In this way, the present study makes an important conceptual contribution to our understanding of the Roma people in Athens. Indeed, understanding the sources of inequality and the mechanisms leading to inequality between people of varying backgrounds is of crucial importance for studying and furthering the rights of all citizens, as outlined in public policy initiatives. In its use of a random Roma sample and multivariate analysis, this study is a methodological advancement over previous studies of Roma employment, and it could inspire new efforts to compare wages by Roma background. 
Based on the Athens Area Sample (2007-2008) Roma women have significantly lower educational attainment than non-Roma women. Interestingly, however, younger Roma have higher graduation rates from high schools than older Roma women. Additionally, Roma women are overrepresented in blue-collar jobs and in the private sector, which are the lowpaid jobs in this sample. The highest wage gaps are estimated for blue-collar occupations, followed by service jobs and white-collar jobs. Moreover, in private-sector jobs we found higher wage gaps against the Roma than those found for public-sector jobs. Hence, in the current study, occupations and sectors were found to have a significant impact on Roma wages. This pattern is consistent with occupational segregation's assumptions (Bergmann, 1996). In addition, the estimations show that Roma women with university or technical school diplomas face lower wage gaps than women with no such educational attainment. This outcome suggests that educated Roma women face a lower wage difference, which is consistent with the statistical theory of discrimination (Arrow, 1998). However, wage gaps are significant across all occupation and sector subgroups and independently of the educational attainment level of the Roma, suggesting that for Roma women the prejudices and distastes (Becker, 1993) they face in the Athenian market are strong. Thus, the study’s results can be evaluated by more than one theory of labor market discrimination, giving us the chance for a multifaceted discussion.

As long as, wage discrimination against Roma women exists this pattern will contribute to the economic loss and inequality which forms the basis for a broader inequality between racial groups, as well as, between women and men and can translate into economic dependence and poverty for the effected women. This study concludes that despite widespread legal protection, taste discrimination in the labor market continues to exist and further efforts are needed to ensure that the right not be discriminated against is implemented effectively. The elimination of prejudice requires deliberate, focused and consistent efforts 
and policies by all parties concerned over a sustained period of time. In addition, from the part of firms, a better means of assessing workers' skill and human capital may contribute to the reduction of statistical discrimination at the individual or group level. Whilst, greater educational achievement would significantly boost the economic status of Roma women. Because lower wages stem from the segregation of Roma to poorly paid occupations, the appropriate policy intervention would occur in the Greek educational and apprenticeship system.

Several factors highlight the importance of this study and the contribution it can make to better understanding Roma workers earnings compared to non-Roma workers. Despite its strengths, most studies have weaknesses that limit the generalizability of the findings and this study is no exception. Importantly, note that the current study makes use of a random sample in those Athenian areas the Roma are strongly believed (based on the available bibliography) to be concentrated. Unfortunately, there are no statistics to declare the percentage of Roma and non-Roma people living in these areas or to other Athenian areas, and we do not have references to draw conclusions regarding Roma socio-economic characteristics in those areas. More importantly, the identified Roma groups have the following characteristics; they live in houses, and in these houses telephone communication is efficient. As a result, this study cannot collect data for other Roma women who live in houses but there is no landline telephones, or even for other Roma denominations, for instance, Nomads who are viewed as the most vulnerable groups among the Roma ${ }^{2}$. Hence, the wage estimations might understate

\footnotetext{
${ }^{2}$ Nomads live in shantytowns, are in most cases self-employed people, and are unable to meet their basic needs. In this study, we do not attempt to review the existing literature of Nomads. Exarchos (1998), Marantzidis et al. (1999), and Karathanassi (2000) provide discussions of many relevant issues regarding Nomads.
} 
wage gaps for all Roma groups. In the current study, Roma women are therefore not a homogeneous population representative of the entire Roma population of Greece, but they might be viewed as the most fully integrated Roma people who live in the country's capital. Thus, the current study should be viewed as exploratory, and the assigned trends for Roma and non-Roma should hold only for the examined areas.

The rest of the paper is divided into five sections. Section 2 offers a theoretical discussion regarding labor market discrimination. Section 3 reviews the literature concerning Greek Roma. Section 4 discusses the descriptive statistics. Section 5 evaluates the estimation framework, presents the empirical estimations and offers a discussion. The last section concludes the paper.

\section{Theories of labor market discrimination}

Labor market discrimination against the Roma population can be classified into three general types (see, Blau et al. 2006). The first is wage discrimination, where the Roma people are paid less than non-Roma people for doing the same work. The second is employment discrimination, where, other things being equal, Roma bear a disproportionate share of the burden of unemployment. The third is occupational discrimination, where Roma have been arbitrarily restricted or prohibited from entering certain occupation, even though they are as capable as non-Roma workers of performing those jobs, and are conversely segregated into other occupations. European Roma Rights Centre (2007) suggests that Roma are very clear about their position in the labor market, and most search for work that is at the lower unskilled end of the labor market, where jobs are menial and low-paid. Among those confirming that they were employed, the type of work that Roma do is very closely correlated with their low levels of education, which reflects their educational attainment level. Unskilled and skilled labor, which includes jobs as tailors and machine workers, and cleaning, are by far 
the most common employment categories. By far the least common is work in shops, offices, restaurants, hotels, teaching and professional managerial positions.

A very informative study carried out by the European Roma Rights Centre (2007) in Bulgaria, the Czech Republic, Hungary, Romania and Slovakia, demonstrates that the ethos of equality in Roma labor market is almost non-existent. The study reveals that Roma receive less pay, terms and conditions of employment than non-Roma counterparts doing the same job. Many firms have a total exclusion policy regarding the employment of Roma and practice across-the-board unmitigated discrimination against Roma applicants. In a multiapplication search for work, there is a very high probability that a Roma job seeker will be told directly by at least one prospective employer, or someone in the company, that he or she is unsuitable for the vacant position due to being Roma. As a result, Roma job-seekers are eliminated and excluded from the application process at the very outset, regardless of their education, qualifications and relevant skills for the job. These factors create very real barriers that lower wages, reduce employability, and exclude many Roma from work ${ }^{3}$.

Being among the most deprived communities, Roma women and men face specific forms of prejudice and social exclusion induced by the negative attitudes of the ethnic majority population. Roma women in particular, coping with the usual difficulties of social inclusion borne by women belonging to the majority population, show additional difficulties aggravated by the specific Roma culture, which is based on traditional and strictly separated

\footnotetext{
${ }^{3}$ Note also that the European Union Agency for Fundamental Rights (2009) suggests that, on average, in Bulgaria, Czech Republic, Greece, Hungary, Poland, Romania and Slovakia, every second Roma respondent was discriminated against at least once in the previous 12 months when looking for work, at work, when looking for a house or an apartment to rent or buy, by healthcare personnel, by social service personnel, at café, restaurant or bars, when entering or in a shop, when trying to open a bank account or get a loan.
} 
gender roles, which may hamper the personal development of the girls and women (European Commission, 2008). Importantly, the 2006 European Parliament's gender based report on Economic Aspects of the Condition of Roma Women comes to highlight that the unemployment rate among adult Roma women is higher than that of the rest of the population (i.e. Roma men, non-Roma men, and non-Roma women). The report emphasizes also that Roma women face higher prejudice in hiring, promotion and wages than Roma men. Moreover, Roma women have less power of negotiation and are more vulnerable than Roma men and non-Roma women to unfair treatment and exploitation, especially when employed in the informal economy and private households. Furthermore, pre-employment constraints that minority women face could dramatically influence their employment status and wages. As long as, some Roma women are excluded from education, this is a crucial factor that results in poor prospects of employment (see European Roma Rights Center, 2005; 2007).

For Greece, the United Nation Committee on the Elimination of Discrimination against Women (2002) suggests that, Roma women face prejudice not only as members of the Roma minority and as women but also as women within their community with its own patriarchy traditions and practices. The study evaluates that each effect (gender, ethnicity) should have a negative impact on women's educational attainment and employment prospects. However, the gender dimension of the discriminatory attitudes that Roma women face is underplayed or unnoticed due to a racial perception of the discrimination Roma population face in general, which is more obvious. It is difficult for Roma women to espouse antipatriarchal views because it often means rejecting hierarchical relations of their race (see, Okin, 1997; Bogdanic, 2005).

Today, Roma discrimination has not been the subject of theoretical consideration in socio-economics. Theoretical explanations of labor market discrimination are concerned with how and why productivity-irrelevant characteristics influence the labor market behavior of 
employers and workers (Swinton, 1977; Burstein, 1990). There is no generally accepted theory that explains labor market discrimination, even though a variety of hypotheses exist. In this section, we briefly review the three main strands of the theoretical economic literature on discrimination in the context of race and ethnicity that can be extended into the realm of concern: Roma discrimination. These strands are distaste for the minority (Becker, 1957; 1986; 1993), statistical discrimination (Arrow, 1973; 1998), and occupational segregation (Bergmann, 1971; 1996). For scholar review surveys see Arrow (1998), as well as, Baumle and Fossett (2005), and Brue et al. (2006).

The distaste hypothesis (see Becker, 1957; 1993) describes discrimination as a preference or taste for which the discriminator is willing to pay. In particular, the taste for discrimination by employers is based on the idea that they want to maintain a physical or social distance from certain groups or that they fear that their customers or co-workers dislike transacting with minorities. Instead of making the common assumptions that employers consider only the productivity of employees, that workers ignore the characteristics of those with whom they work, and that customers care only about the quality of the goods and services provided, Becker suggests that discrimination coefficients incorporate the influence of characteristics unrelated to productivity, such as tastes and attitudes towards Roma identity (see, England, 1994; and Jaret, 1995). Following this line of thinking, employers may offer Roma a lower wage compared to the non-Roma in order to equalize the unit cost of labor once psychic costs are factored in. So long as employers' prejudices persist, the size of the Roma penalty will be directly related to the strength of the employer's prejudice, and wage discrimination will be practiced consistently against the Roma by prejudiced agents. However, if the distaste for the Roma population is high enough, employers will prefer not to employ Roma workers in their firms. A few studies test discrimination through surveys that isolate and evaluate Becker's (1957; 1993) theory regarding ethnicity (Riach and Rich, 1991; 
Bertrand and Mullainathan, 2004; Carlsson, and Rooth, 2007; Drydakis and Vlassis, 2010), sex (Riach and Rich, 1995; Petit, 2007), sexual orientation (Weichselbaumer, 2003; Drydakis, 2009; Drydakis, 2011a), health (Drydakis, 2010a; Drydakis, 2010b) and religious affiliation (Drydakis, 2010c). All these studies confirm that distastes against minority groups take place in the labor market.

The statistical theory of discrimination (see Arrow, 1973; 1998) may also explain the lower wages earned by the Roma population. The common hypothesis embraced by neoclassical economists is that competition in a capitalist economy decreases the impact of discrimination. Discrimination imposes a cost on the employer, and a profit-driven employer will thus avoid racist hiring policies. As a result, statistical discrimination predicts that unequal treatment is a result of a profit-maximizing response by employers to uncertainty about the actual productivity of individual workers. Meanwhile, real or subjective distributions favor a certain group, such as non-Roma workers, who then receive preference. In a world of imperfect information, employers face risks regarding workers' productivity, and specific characteristics become inexpensive screening devices (see, Pager and Karafin, 2009).

Following the Statistical theory, the rational employer will seek to obtain the maximum amount of information about the expected profitability associated with prospective tenants at the lowest cost. If employers believe that there is a systematic difference between Roma and non-Roma women in their reliability, aptitude, and job stability, then sufficient conditions exist to create a permanent differential in wages. The belief of employers and other influential groups that Roma are less productive can be self-fulfilling. In this situation, discrimination is not the consequence of exogenous preferences but a result of the profitmaximizing behavior of risk-averse employers. Unlike in the Taste theory, in the Statistical theory, employers’ prejudices are irrelevant. However, if employers' uncertainty regarding 
Roma women productivity is strong enough, they will not employ Roma to their works, or they employ Roma in jobs in which it is easier to monitor their productivity or in jobs for which turnover is not problem. Empirical evidences of statistical motivations are offered by many studies (Davis, 1987; Altonji and Pierret, 2001; Pinkston, 2003; Dickinson and Oaxaca, 2009; Drydakis, 2011b).

One additional factor identified as a major cause of the ethnic wage gap is the difference in occupations in which majorities and minorities are employed. Bergmann's (1971; 1986; 1996) segregation argument is that as the two groups are employed in quite different occupations and that large numbers of racial minorities are employed in "minority-dominated occupations” on relatively low wages, there arises, on average, a large wage gap between majorities and minorities. The hypothesis is premised upon the existence of a mixture of minority-dominated occupations and majority-dominated occupations in the labor market. According to the hypothesis, minorities are shut out of majority-dominated professions and flood into minority-dominated occupations. Working on the basis of the segregation hypothesis, relative wages end up lower in "minority-dominated occupations," in which a high proportion of minorities are employed, because of excess supply; conversely, relative wages are higher in "majority-dominated occupations," in which low proportions of minorities are employed, because of lower supply (see, Brue et al. 2006). The reasoning behind the segregated markets can be attributed to both distaste for minorities and statistical motivations, which are assumed to be higher in jobs with higher status (i.e., white-collar jobs) (see, Bergmann, 1996).

Notice also that the Crowding theory suggests further that as long as one group is overrepresented within one unskilled low-paid occupation, mainly based on employers' prejudices, this fact will increase the supply for this occupation and as a result will have strong depressing effect on wages (see, Lewis 1996). Thus, as long as Roma and non-Roma 
workers are crowding to skilled and unskilled occupations, this distinction may contribute to wage gaps between these workers. As Lewis (1996) suggests, crowding can only occur in the presence of occupational segregation. Therefore, the concepts are related, but it is proper to mention the two theories. Many empirical studies show that segregation and crowding into low-wage workplaces have a particularly significant negative impact on minority groups' relative wages, and also a high presence of minority tends to depress workplace's wages (Groshen, 1991; Macpherson and Hirsch, 1995; Lewis, 1996; Catanzarite, 2000; Bayard et al. 2003; Amuedo-Dorantes and De la Rica, 2006; Simon et. al. 2008; Drydakis, 2011b).

There is a rich literature about racial and ethnic discrimination in labor markets that fruitfully can be extended into the evaluation of Roma discrimination in the labor market. Because of employers' distaste, employers' perception that Roma workers are not as productive, and/or overrepresentation of unskilled occupations, Roma people may receive substantially lower wages in the market. While as long as Roma women are more vulnerable to societal discrimination than Roma men and non-Roma women, the various discrimination hypotheses are expected to be more pronounced in their case. The discrimination models have drawn attention to various microeconomic issues that need to be incorporated into the theory of Roma discrimination in the labor market. In addition, owing to its political significance in Europe, social scientists should attempt to offer economic explanations for the phenomenon of Roma discrimination, drawing largely on the European experience for empirical reference.

\section{Greek Roma}

In Greece social research on the Roma is scarce due to the lack of ethnically differentiated data. Some studies focus mainly on historical periods, such as how and when 
the Roma came to Greece ${ }^{4}$ (Komis, 1998; Vaxevanoglou, 2001). Moreover, few academic studies evaluate Roma characteristics, customs, traditions, and daily habits in specific areas from an anthropological perspective (Kozaitis, 1997, 2002). Currently, the share of the Roma within the total Greek population varies between 2-3\% (ROM Network, 2000). The Roma people are officially registered as Greek citizens with no reference to their origin. A majority of the Roma are Orthodox Christian and have taken Greek names, and most Roma speak the Greek language (Komis, 1998; Hunt, 1993; ROM Network, 2000; Vaxevanoglou, 2001). They enjoy by constitutional law all civic and political rights entitled to Greek citizens ${ }^{5}$. With respect to their community, particular lifestyle and needs, Roma have been recognized by the Government as a socially vulnerable group of the Greek population. In recent years, the expression "Greek-Roma” has emerged as the politically correct term to refer to Greeks with a Roma background.

The Roma in Greece live scattered on the whole territory of the country, but a large concentration in the bigger cities, mainly in Athens and Thessalonica. Although a large number of Roma has adopted a sedentary and urban way of living, there are still settlements in some areas (Komis, 1998; Vaxevanoglou, 2001; European Roma Rights Center and Greek Helsinki Monitor, 2003). How Roma concentrate in urban space has been the focus of

\footnotetext{
${ }^{4}$ The centuries-old Roma presence in Greece had become well entrenched by the time of the Greek War of Independence from Ottoman rule, otherwise known as the "Revolution of 1821.” Until 1955, the Roma were stateless. Since then and gradually until 1978, they were all granted Greek citizenship to allow them to acquire an identity card or, in cases when they resided in a municipality, to allow them access to social benefits (ROM Network, 2000).

${ }^{5}$ The Roma people of Greece participate in and constitute political parties, they vote and get elected, and they organize themselves in collective bodies and participate in public life and local government structures.
} 
different and complementary theories in sociology, geography, politics, and economics (Schelling, 1969; Bourne, 1976; Logan and Molotch, 1987; Portes and Sensenbrenner, 1993; Ratcliffe, 1998; Tickamyer, 2000; Wilson, 2001). Three hypotheses seek to explain the persistence of the residential concentration of Roma across Athens: economic differentials, discrimination in housing, and neighbourhood preferences. The economic hypothesis contends that concentration began and persists because Roma in Greece live where they can afford the cost of living. Specifically, the economic theory suggests that Roma people who are driven by their budget constraints choose to concentrate in mostly working-class communities. On the other hand, the racial discrimination hypothesis argues that Roma concentration persists because of the societal discrimination they face in middle- and upper-class areas by landlords, real estate agents, and non-Roma neighbours, who constitute the majority. The preference hypothesis posits that Roma in Greece wish to live in more homogeneously Roma neighbourhoods. Origin heritage includes factors such as cultural roots and 'religion and memories'. This theory maintains that origin heritage is a significant motivator for Roma to live in the same space. All the theories described above remain controversial given the absence of empirical evaluation. In fact, a combination of these theories may explain the concentration of Roma in Greek multiethnic communities.

Due to the lack of data, only speculations are made regarding demographics, societal participation and employment, of the Greek Roma, sustaining confused pictures of their daily life and numbers. However, if we focus on suggestions made by the European Roma Rights Centre (2007) it seems that throughout European countries, the Roma people are not characterized by strong educational attainment and are most often employed in unskilled work, which provides low wages. Importantly, the general trends conclude that the risks of social exclusion are particularly relevant for Roma women. Indeed, the Directorate-General for Employment, Social Affairs and Equal Opportunities of the European Commission 
(2008), evaluating qualitative information provided by the national experts of 30 European countries, shows that Roma women in the labor market are characterized by higher unemployment rates than those given for native women and minority men. This trend is supposed to be due to their domestic role in the family, especially in those Roma communities where gender roles presume the lack of qualifications that are important for employment chances. Nevertheless, as the study notes, these trends are not uniform among Roma denominations, and we should be careful to draw general conclusions. Across European countries, as well as within countries, there are significant differences between Roma groups.

\section{Data set}

Data were gathered from September 2007 through June 2008 as part of the Athens Area Study (AAS), conducted by the University of Crete. The 2007-2008 AAS is one component of the Multi-City Study of the Scientific Centre for the Study of Discrimination (SCSD), which has collected information on labor market variables and which focuses on the Roma population. The data set focuses on the 16 Athenian municipalities in which Roma populations are concentrated, and which are perceived as working-class areas ${ }^{6}$. Those areas were identified by considering the references made by the available literature (Hunt, 1993; Kozaitis, 1997; Exarchos, 1998; Komis, 1998; Marantzidis et al. 1999; Karathanassi, 2000; ROM Network, 2000; Vaxevanoglou, 2001; Kozaitis, 2002; European Roma Rights Center and Greek Helsinki Monitor, 2003; Pavlou et al. 2009). The current AAS consists of random telephone-based surveys where employed ${ }^{7}$ women aged 18 to 65 years were selected to

\footnotetext{
${ }^{6}$ For a classification of Athenian Areas as working-, middle-, and upper-class areas, see Drydakis (2010d;e).

${ }^{7}$ The employed individuals were employed by firms. Self-employed individuals (i.e., those who have their own business) were not included in the survey.
} 
provide individual information on a variety of demographic characteristics. Wage is measured as a continuous variable. The AAS constructed an hourly wage measure by dividing the last month's wages by self-reported working hours per month ${ }^{8}$. Surveyors asked, "What is your best estimate of your wage last month before taxes and other deductions?” The wages variable is the natural logarithm of hourly earnings (called NLHW).

To investigate the Roma identity, adult workers were asked: 'The next question is about Roma origin. Are you Roma or, as said, Athinganos? ${ }^{\prime 9}$. The Roma origin is a dummy variable called ROMA, taking the value of one if the respondent was Roma, and zero otherwise. At this point, two issues in economic analyses of origin identity are important to discuss. First, an important factor influencing the potential for Roma background to decrease wages through employer discrimination is the employers’ ability to distinguish between Roma and non-Roma. To the extent that an employer only imperfectly observes Roma employees, any evidence of discrimination we find would understate the extent of discrimination against the Roma people. Nevertheless, Roma families in Greece are proud of their heritage and continue to follow their cultural traditions. Thus, we believe it is not very likely that an employer would fail to detect the Roma origin of a worker. Second, 'underreporting' is a concern in every study that infers origin from telephone-based interview data. Within the Roma community, it may be that a higher percentage of higher-earning female are willing to identify themselves as Roma. Thus, marginalized segments of the Roma population in Athens are probably missing from the data set. Both instances of untruthfulness, if uniformly

\footnotetext{
${ }^{8}$ By using this specification, part-time workers and homemakers were included in the sample.

${ }^{9}$ The term Roma was not commonly used in Greece until recently. Athinganos is the term used for administrative purposes for Roma in Greek. This term is fully understandable in the Greek region and includes relevant sub-groups. The AAS used both expressions in case individuals were unfamiliar with the Roma term.
} 
distributed over all kinds of workers, would tend to bring the Roma and non-Roma averages closer together, biasing a test to detect differences against finding any. Nothing suggests that the above-mentioned two points cause greater bias than in comparable studies. Also, we have to highlight that a few marginalized Roma people who live in houses might not have landline telephones. Thus, this study might capture the most fully integrated Roma women in Athens who live in houses and have a telephone connection.

There are numerous factors besides Roma identity that may influence wage levels. To isolate the effect of Roma origin on wages, we must appropriately control for all other factors that affect wages and that correlate with Roma origin. Some of these factors pertain to individual productivity. The productivity variables used in the study were age, education, health status, and occupation. The variable AGE measured the individual's years of age. The variable MARR was set equal to one if the woman was married and zero otherwise. The variable CHIL measured the number of the surveyed individual's children. To capture the possible effects of disability and disease, the variable DIS was set to one if the woman's activities were limited by poor health; otherwise, it was zero. To be comparable to previous research, we defined the disability status using the self-reported response to the question concerning conditions that limited the individual's ability to work (Baldwin and Johnson, 2000).

The variable SCHOL was set to one if the respondent had completed the minimum mandatory education level and was zero otherwise. The variable GRAD was set to one if the respondent had graduated from high school and zero otherwise. The variable UNIV was set to one if the respondent had a university or technical school diploma and zero otherwise. The coefficients on these variables measure the effects of degree completion compared to workers who did not receive a comparable educational level. The variable CS was set to one if the individual had computer skills and zero otherwise. The variable ENGL was set to one if the 
respondent had knowledge of English and zero otherwise. The variable DRIV was set equal to one if the respondent had a driving license and zero otherwise.

The variable EXPER measures the woman's years of actual working experience. Two dummy variables for occupational categories were included in the analysis. The variable WHITE was set to one if the individual's occupation was among white-collar occupations; otherwise, it was zero. Similarly, the variable BLUE was set equal to one if the individual's occupation was among blue-collar occupations; otherwise, it was zero. In both cases (i.e. WHITE; BLUE) the omitted category was those jobs among service occupations (SERV). For deeper occupational control, an additional variable was considered. The variable PUBL was set to one if the worker was employed in the public sector and zero otherwise. The omitted category was those jobs in the private sector (PRIV). The variable INSI was set to one if the worker worked in the municipality in which her household was located and zero otherwise. Finally, the dummies MUN_1 up to MUN_16 represent region-specific fixed effects (16 municipalities). For convenience, variables definitions are summarized in the Appendix.

\section{Descriptive statistics}

By using self-reported Roma background, we are able to separate non-Roma from Roma women. Since the non-Roma's status is the implicit norm, indicators used to measure Roma women's status tend to focus on the extent to which Roma women achieve parity with non-Roma women in the traditional arenas of public life, education and employment. Our sample of adults consists of 4,679 non-Roma and 961 Roma. The AAS represents a proportion of Roma individuals on the order of $17.0 \%$. We present variable means stratified by non-Roma and Roma identity. Table 1, shows the descriptive statistics. At first glance, 
Roma have lower hourly wages (natural log) than non-Roma ${ }^{10}$ (3.12 versus 3.50, respectively, $\mathrm{p}=0.00$ ). For a better evaluation, we can concentrate on each occupation and sector. We can see that in all subgroups, Roma workers were found to receive lower wages than non-Roma. All differences are significant at the $1 \%$ level. Moreover, we can observe that, for both Roma and non-Roma workers, the blue-collar jobs constitute the least well-paid occupation, followed by service jobs and white-collar jobs. Furthermore, between public and private sector, the latter is the least well-paid sector for all workers. Those workers being in whitecollar occupations and in the public sector gain the highest wages in the AAS sample ${ }^{11}$.

[Table 1]

To continue with, the results indicate that Roma and non-Roma women have nearly the same average age (33.3 versus $35.8, \mathrm{p}=0.14$ ). Roma are more likely to be married than

${ }^{10}$ Note that the average monthly wage (raw statistics) for non-Roma workers is $€ 1.318$, while for Roma women it is €924. Based on the General Confederation of Greek Workers, for the period 2007-8, the minimum legal wage for unmarried workers without experience was $€ 720$. For married workers without experience, the minimum legal wage was $€ 800$. In each group, every three additional years of working experience yielded a €60 increase in the minimum wage.

${ }^{11}$ The white-collar sector contains independent and subordinate sectors. White-collar sector occupations usually require specific skills or prior training. It is only in this sector that the wages of workers are tied to their productivity. On the other hand, the blue-collar sector demands unskilled, rudimentary, menial, repetitive, interchangeable, and substitutable or expendable labor. Schooling and on-the-job training are irrelevant for these workers' wages. The wage profile in this sector is flatter than the earnings profile in the white-collar sector. The main determinant of wages in the blue-collar sector is hours of work. 
non-Roma ${ }^{12}$ (84.4\% versus $\left.65.9 \%, \mathrm{p}=0.00\right)$. In addition, Roma have more children than nonRoma (1.43 versus $0.87, \mathrm{p}=0.00)^{13}$. Moreover, Roma are less likely to have health limitations than non-Roma (4.3\% versus $6.9 \%, \mathrm{p}=0.00)$.

Roma and non-Roma women devote a significantly different number of years to education. Roma are significantly less likely to have completed minimum mandatory education than non-Roma (45.9\% versus $96.3 \%$, $\mathrm{p}=0.00$ ). As a result, Roma are less likely to have a high school diploma than non-Roma (18.4\% versus $86.1 \%$, $\mathrm{p}=0.00)$. Similarly, only a small proportion of Roma people have a university or technical school degree $(9.5 \%$ versus 47.2\%, $\mathrm{p}=0.00$ ). Furthermore, Roma are significantly less likely to have computer skills and English knowledge than non-Roma ${ }^{14}$ (7.4\% versus $65.2 \%, \mathrm{p}=0.00$, and $7.3 \%$ versus $47.3 \%$, $\mathrm{p}=0.00$, respectively). Moreover, Roma women are less likely to have a driving license than non-Roma (5.2\% versus 58.9\%, p=0.00). In addition, Roma have more years of actual working experience than non-Roma (16.1 than $12.9, \mathrm{p}=0.00)$. If we subtract the individual's age from years of working experience, we see that Roma women start their working careers at

\footnotetext{
${ }^{12}$ Notice that almost all Roma women who are more than 22 years of age are married. On the other hand, the great majority of non-Roma women who are more than 33 years of age are married.

${ }^{13}$ Notice that due to the fact that Roma sample is entirely non-immigrant and the non-Roma sample includes a small fraction of immigrants (6.3\%) we limit the analysis to nonimmigrants and we therefore report the results as a differences between Greek Roma and Greek non-Roma.

${ }^{14}$ Note that if we concentrate on Roma and non-Roma women who are less than 20 years of age, they have comparable rates of mandatory education. Also, if we consider Roma and nonRoma who are older than 50 years, only a small proportion of the former have completed mandatory education.
} 
17.2 years of age, and non-Roma women start their working careers at 22.9 years of age. The interpretation might be clear. Since Roma people cease their education early, they start employment at a younger age. Based on the AAS sample, Roma people have approximately five additional years of actual working experience than non-Roma. The present study indicates that Roma women have lower educational levels but more working experience. On one hand, Roma may have lower wages because of their lower educational level; on the other hand, they may earn more than non-Roma due to their greater working experience. Thus, we have two opposing factors that may affect the observed wage gap. Nevertheless, even before performing an multivariate analysis, the data clearly indicate that Roma have lower monthly wages.

A potentially important difference between Roma and non-Roma is their occupational category. Roma individuals are significantly less likely to be employed in white-collar jobs than non-Roma (5.5\% versus 40.6\%, p=0.00). Concomitantly, Roma are significantly overrepresented in blue-collar jobs compared to non-Roma ( $88.7 \%$ versus $46.5 \%, \mathrm{p}=0.00$ ). Moreover, Roma are less likely to work in service occupations than non-Roma (5.5\% versus 12.5\%, $\mathrm{p}=0.00$ ). A small number of Roma are employed in the public sector compared to nonRoma (13.1\% versus 43.9\%, $\mathrm{p}=0.00)$. Also, more Roma people are employed in the private sector than non-Roma (86.7\% versus 55.9\%, $\mathrm{p}=0.00$ ). In the AAS sample, there is strong segregation; which refers to the fact that Roma and non-Roma do different types of work and are employed in different sectors. As measured by the index of occupational segregation (see Duncan and Duncan, 1955; Cunningham and Zalokar, 1992; Lewis, 1996), Table 2, for bluecollar jobs, the segregation index is 2.1 times higher than the index that holds for white-collar jobs. A smaller difference, 1.9, is observed between the blue-collar jobs and service jobs. We can see also that the index for the public sector is 1.7 times higher than the index for the private sector. 
[Table 2]

In the AAS sample, there is also a crowding effect, as long as a high proportion of Roma workers are located in the same occupation, and sector. One measure of such crowding is the coefficient of variation (see Lewis, 1996). In Table 3, the great dispersion indexes of Roma workers indicate that many Roma are employed in some occupations and sectors while only a few are employed in others. The coefficient of variation index for occupations is 2.8 times higher for Roma workers than it is for non-Roma. Similarly, for sectors the index is 5.2 times higher for Roma workers than non-Roma. The persistent overrepresentation in the lowpaid occupations and sectors would produce an ongoing gap in occupational status, which would translate into differential wages between Roma and non-Roma (see section 6).

[Table 3]

\section{Estimation framework and discussion}

Human capital theory, as formulated by Mincer (1974) and Becker (1975), evaluates how improvements in the skills and talents of workers influence future real income. An increase in skill increases productivity and wages, albeit at the cost of foregone income. Since more human capital increases productivity, it is in the interest of employers to reward these workers with higher wages. Wage profiles over time are steeper for the more educated and more able workers. As a result, human capital theory attributes wage differentials to worker differences in individual skill levels. In this study, we test the hypothesis that the Roma population has statistically different wages than those earned by the non-Roma while controlling for differences in labor market experience, educational levels, occupations, and other characteristics.

The empirical work is based on the standard human capital wage equation developed by Mincer (1974). The wage equation, written below, relates the calculated wages to dummy 
variables for the demographic and control variables. We use the natural logarithm of the wage variable, which increases the efficiency of estimation because it increases the extent to which the variable approximates a Gaussian distribution. It also allows for an easier interpretation of the coefficients as percentages. There are two types of individuals. The non-Roma are represented by NR, and the Roma are represented by R. For each of these types, the wage offer equation is given by:

$W_{i j}^{O}=\beta_{1 j} X_{1 i j}+v_{1 i j}, \quad(\mathrm{j}=\mathrm{NR}, \mathrm{R})$

where $W_{i j}^{O}$ denotes the logarithm of the (offer) wage, $X_{1 i j}$ is a vector of productivity-related characteristics for individual $\mathrm{i}$ of type $\mathrm{j}, \beta_{1 j}$ are the associated rates of return, and the $v_{i j}$ is a mean-zero stochastic error representing the influence of unobserved variables affecting $W_{i j}^{O}$.

An often-used methodology of studying labor market outcomes by groups is to decompose mean differences in log wages based on regression models in a counterfactual manner. The procedure is known in the literature as the Blinder-Oaxaca decomposition (Blinder 1973; Oaxaca 1973) and divides the wage differential between two groups into a part that is "explained" by group differences in productivity characteristics, such as education and work experience, and a residual part that cannot be accounted for by such differences in wage determinants. This "unexplained" part is often used as a measure for discrimination, but it also subsumes the effects of group differences in unobserved predictors. The difference in wage offers between non-Roma (NR) and Roma (R) employees can be decomposed as

$$
\bar{W}_{N R}-\bar{W}_{R}=\left(\bar{X}_{N R}-\bar{X}_{R}\right) \tilde{\beta}_{N R}+\bar{X}_{R}\left(\tilde{\beta}_{N R}-\tilde{\beta}_{R}\right)
$$

The left-hand side of equation (2) then represents the difference in mean wage offers between non-Roma and Roma workers. The first term on the right-hand side represents that 
part of the difference in wage offers that is attributable to differences in productivity, called the "explained gap," and is considered the non-discriminatory component of the racial wage gap, while the second term is called the "unexplained gap" and is considered to be due to discrimination.

Table 4 presents coefficients from equation (1). In terms of specific coefficient estimates, these are largely in accordance with the usual predictions. Age, marital status, and number of children have positive and generally statistically significant effects on wages in the two groups. On the other hand, health limitations have always negative and significant effects on wages. Empirical analysis shows that signs of the coefficients of the variables that measure human capital are consistent with human capital theory. Wages are higher for those with qualifications relative to those without qualifications in each level, with the coefficients generally increasing in magnitude as one progresses up the qualifications hierarchy. As can be seen, however, Roma generally experienced fewer returns per unit of human capital.

\section{[Table 4]}

Turning to other variables in these regressions, actual working experience has a positive and significant correlation with wages. Nonetheless, higher returns are observed for the non-Roma employees. The industry dummies have a fairly consistent effect across the two groups, with higher significant wages in white-collar jobs. In addition, for non-Roma and Roma, the effect of having a public job on wages is positive and statistically significant. In all cases, Roma experienced fewer returns on their occupations/sectors than non-Roma. Moreover, if the employers' workplace is in the same municipality as the individual's household, the effect on wages is positive but insignificant for both specifications.

In Table 5, the decomposition output reports the mean predictions by groups and the differences between them after controlling for occupations and sectors. In the AAS sample, Panel A, the mean of the log wages is 3.501 for non-Roma and 3.129 for Roma, yielding a 
raw wage gap of 0.372 . As the model indicates, the standard application of the BlinderOaxaca technique is to divide the wage gap into a part that is explained by differences in determinants and a part that cannot be explained by such group differences. The increase of 0.126 in Panel B indicates that differences in endowments account for about $33.8 \%$ of the wage gap. The remaining 0.246 indicates that for Roma workers, the "unexplained" component typically constitutes somewhat more than half of the differential between the nonRoma workers. To be specific, a gap of $66.2 \%$ remains unexplained and is statistically significant. The latter gap is usually attributed to discrimination, but it is important to recognize that it also captures all potential effects of differences in unobserved variables.

[Table 5]

In this study, we cannot reject the hypothesis that there is a non-trivial incidence of Roma discrimination in the market, even when we control for educational characteristics and occupations. Human capital theory suggests that differences in pay can be explained by differences in workers' education, which tend to increase pay because of their positive impact on productivity. To the extent that human capital variables are unable to explain pay differences between Roma and non-Roma, the remainder of the assigned differential is generally interpreted as evidence of discrimination, caused perhaps by distastes (Becker, 1975; 1993) and/or statistical motivations (Arrow, 1973; 1998) against Roma, and/or occupational segregation (Bergmann, 1971; 1986; 1996). As a result of discriminatory practices due to race backgrounds, two equally qualified groups of individuals were treated differently. Importantly, note that the wage levels earned by Roma women might also be aggravated by the gender wage gap that characterizes Greek women ${ }^{15}$.

\footnotetext{
${ }^{15}$ Papapetrou (2007), using the European Union - Social Inclusion and Living Condition data set, suggests that $41.7 \%$ of the wage differential between Greek men and women in 2003 cannot be explained on the basis of different productive characteristics. Thus, Roma women
} 
While available research based on human capital explains existing race inequalities to some degree, there remain unexplained race penalties that could stem from the discriminatory allocation of Roma to less advantageous occupational positions. In Table 5, Column 3, we have re-estimated Equation (2) without controlling for occupations and sectors. Nevertheless, we observe that the results do not vary a lot. This is an expected result, as long as in the AAS sample, the vast majority of the Roma women are overrepresented in one specific low-paid occupation (blue-collar job). Hence, firm conclusions cannot be made by the latter analysis. We have then to extend the current analysis by including separate comparisons of Roma and non-Roma workers for each occupation. Holding the occupational status constant, we are able to observe direct wage gaps. In addition, these comparisons, which result in three estimates of the wage differential, seem to be desirable, as a range is presented with endpoints that represent the maximum and minimum magnitudes of the wage gap among these occupations.

In Table 6, white-collar jobs present the lower bound on the wage differential between Roma and non-Roma. A statistically significant gap of 56.8\% remains unexplained. Bluecollar jobs present the upper bound on the wage gap. The unexplained component accounts for $77.1 \%$ and is also statistically significant. For service jobs, the unexplained part is on the order of $61.1 \%$. In sum, we calculate the unexplained part for Roma as a range between $56.8 \%$ and $77.1 \%$ among the three occupations of interest. Overall, even within the same occupational category, Roma women earn less than similarly qualified non-Roma women. However, in the case of blue-collar occupations, the gaps reach their higher value. On the one hand, the descriptive statistics show that Roma women are segregated in blue-collar jobs; on the other hand, as the estimations declare, Roma women face higher wage penalties in these

of Greece are expected to face a complex set of negative effects that influence their wage levels. The knowledge of the various effects that add to the gender wage gaps are therefore important for being able to isolate each effect and make evaluations. 
jobs. It seems that the segregation and crowding of Roma workers to the low-skilled jobs drive employers to practice higher wage differentials against them. Bergmann’s (1971; 1986; 1996) theory of occupational segregation is validated; the current results demonstrate that occupational segregation results in lower wages for Roma women, and higher wages for nonRoma women. Thus, in this sample, each occupation is proven to have a different effect on wages earned by Roma, and we should pay attention to this factor. Further in Table 7, examinations of additional regression subgroups based on sectors consistently showed wage penalties for Roma women. As the decomposition results indicate, Roma women employed in the public sector are expected to face lower wage gaps (54.8\%) as compared to those employed in the private sector (75.4\%). In the public sector, workers might be more protected by discriminatory treatments, as the pay criteria are specific and analogous to workers' experience and qualifications. Nevertheless, even among Roma public workers wage penalties are still large in magnitude and significant. Hence, prejudices against Roma women are likely to be widespread in the Athenian labor market. It seems that employers have to compensate their distastes (Becker, 1975; 1993) from having to employ Roma women by imposing wage penalties on them.

\section{[Table 6]}

\section{[Table 7]}

Finally, it is of great interest to examine whether Roma women's higher educational attainment could eliminate or downsize the wage gaps. If Roma women with university or technical school diplomas proved to face lower wage gaps than those Roma women with high school or minimum mandatory education degree, then the assigned trend should be consistent with the employers' statistical motivations (Arrow, 1973; 1998), so long as employers value education and skills in order to make evaluations regarding employees’ productivity. In Table 8, we present decomposition outcomes by education level. The unexplained wage part for 
those Roma having a minimum mandatory education degree is $68.9 \%$. On the other hand, Roma workers having graduated from a high school face a lower unexplained wage gap on the order of $64.8 \%$, while for those Roma having a university or technical school diploma, the unexplained wage gap has a lower level on the order of $60.5 \%$. The estimations suggest that as the education level increases, the wage gap decreases. Thus, statistical motivations are present. However, we observe that the differences among the education subgroups are not large enough. While even within the higher level of education the wage gap is still significant and do not disappear. We can thus conclude that employers’ prejudices (Becker, 1975; 1993) dominate Roma wages in the market regardless of the level of education attained by Roma.

\section{[Table 8]}

Overall, the estimated trends are consistent with the most competitive theories of discrimination reviewed in this study. By examining various subgroups, we suggest that taste, statistical motivations and occupational overrepresentation are responsible and present the implications of each factor for the evidence of wage gaps against Roma women.

Provided that identifying the sources of racial differences in wages is crucial in implementing effective policy decisions so as to reduce them. Neumark (1999) suggests that from a policy perspective, whether taste discrimination or statistical discrimination plays a major role in differences in wages between races is significant. If taste discrimination accounts for the unexplained lower wages of Roma women, then antidiscrimination legislation may be the only appropriate response. Actually, International Labor Office (ILO, 2007) suggests that the most obvious means of dealing with discrimination is through direct governmental innervations. In order racial discrimination to be eliminated ILO (2007) highlights a three-pronged approach: (i) revision labor laws which not only prohibit discrimination, but which provide for a positive duty to prevent discrimination and promote equality, (ii) better implementation of existing laws, rules and regulations which would 
counter the discrimination of minority women in the labor market, (iii) implementation of functioning control mechanism and their support by all relevant bodies.

However, if statistical discrimination is important, then a better means of assessing workers' productivity, skill and ability may contribute to the reduction of discrimination at the individual or group level (see, Altonji, and Pierret, 2001). As workers accumulate experience on the job, employers may acquire new information about performance/abilities and reevaluate wage contracts and promotion decisions. In addition, because lower wages stem from the allocation of Roma to poorly paid occupations, the appropriate policy intervention would also occur in the Greek educational and apprenticeship system. That is, efforts must be made to reach Roma children before they enter the labor market to ensure that they are in educational tracks and apprenticeship positions that are institutionally connected to betterpaid occupational categories. As the descriptive statistics revealed, very few Roma women complete high schools in Greece, despite the payoffs in terms of employment and wages, and greater educational achievement would significantly boost the economic status of Roma, particularly in the new generation (see also Higginis, 2010). In the socio-economic story of specialisation, the expectation of marriage and acceptance of traditional gender roles may drive the relationship between Romani background and wages (Becker, 1981). Young Roma women may invest less in human-capital formation than their non-Roma counterparts because of rational, racial-based expectations about their future partners and domestic arrangements. Bergmann (1974; 1996) suggests that upgrading the quantity and quality of schooling received by minority population will enable them to become more competitive with majority population. Bergmann (1996) evaluates also that the achievement of a tight labor market through the use of appropriate monetary and fiscal policies might attack the problem of discrimination. Actually, on the one hand, an expanding economy makes it increasingly 
expensive for employers to indulge their tastes for discrimination, on the other hand, tight labor markets help to overcome stereotyping.

Importantly, however, additional unobservable factors may have contributed to the wage gap. There is a concern that the wage discrimination effect may be overestimated as long as the estimated model does not capture actual variables that measure the various 'skills' and 'abilities' of workers. A critical non-observable variable is the actual skill of workers, which is separate from either education or work experience. This variable captures to what degree an individual is actually able to perform a certain task and is also related to work motivation. Unfortunately, the AAS does not contain such measures to take them into account. Someone could claim that the assigned unexplained wage gap may actually be due to unobservable skill variables and not due to discrimination. Hence, a complicated problem lies in determining where unobservable characteristics end and minority discrimination begins. This drawback is a most common concern that arises in the literature (see, Heckman et al. 2006).

To conclude this study, in the context of a growing demand for evidence-based social policies for Roma population, the issue of empirical research has become increasingly important. Both governments and civil society organizations demand information on the numbers and characteristics of Roma groups in order to identify factors relating to their social and economic position, to help expose discrimination, or to assess measures to combat it. The empirical research on Roma discrimination is necessary for sensitizing the public and policy makers as to extent and nature of discrimination and related injustices, as well as for planning positive action measures and other antidiscrimination initiatives. Surveys should aid organizations to ensure that their policies comply with equal treatment laws, and be used for judicial processes in proving or rebutting claims of unfair treatment (see, Makkonen 2007). Driven by the current findings, if economic conditions are to improve for Roma women in 
Greece, policies must focus on all of parameters that was discussed in order to combat wage differences in the labor market. Given the legal actions that have the potential to affect the Roma, it is increasingly important to understand the relationship between the Roma population and labor market outcomes.

\section{Conclusion}

Discrimination based on Roma background has been ignored by the socio-economic literature, despite evidence from other disciplines on the effects of ethnic and racial origin. In the current study, we report estimates of the economic effect of Roma background for women in the Greek labor market, using the Athens Area Study from 2007-08. By utilizing data drawn from 16 multiethnic municipalities in which Roma live we find strong evidence that is consistent with the hypothesis of prejudices (Becker, 1957; 1993) against Roma women regardless of their educational attainment and job status. In addition, evidence of statistical motivation (Arrow, 1973; 1998) is found to be present; Roma women with a higher education level face lower wage gaps than those women with less education. Moreover, Roma workers are found to be segregated (Bergmann, 1971; 1996) in low-paid jobs and to face there the highest wage penalties. Currently, Roma women do not appear to face a level playing field in the Athenian labor market, even four years into the national implementation (2005/3304) of European antidiscrimination employment legislation (2000/78).

The current estimations suggest that prejudices against Roma women are blatant in the Athenian labor market. This type of discrimination requires deliberate, focused and consistent efforts and policies by all parties concerned over a sustained period of time. There is a need for better implementations of existing laws, rules and regulations which would counter the discrimination of minority women in the labor market (Neumark, 1998; ILO, 2006). In addition, a better means of assessing workers' skill may contribute to the reduction of 
discrimination at the individual or group level (Arrow 1998; Altonji, and Pierret, 2001; Brue et al. 2006). Finally, efforts must be made to reach Roma children before they enter the labor market to ensure that they are in educational tracks and apprenticeship positions that are institutionally connected to better-paid occupational categories (Bergmann, 1996; Higginis, 2010).

The current study should be viewed as exploratory, and the assigned patterns for Roma and non-Roma are strictly applicable only to the time and place from which the sample was drawn; in the current study the Roma people might be viewed as the most fully integrated Roma people who live in the country's capital. The systematic socio-economic study of female minority groups is valuable for both its policy relevance and its potential to inform social scientists and policy-makers about the functioning of the labor market. 


\section{References}

Altonji, J. G. and Pierret C. R. (2001). Employer Learning and Statistical Discrimination. Quarterly Journal of Economics, 116:313-350.

Amuedo-Dorantes, C. and De la Rica, S. (2006). The Role of Segregation and Pay Structure on the Gender Wage Gap: Evidence from Matched Employer-Employee Data for Spain. Contributions to Economic Analysis and Policy, 5:1498-1523.

Arrow, K. J. (1973). The Theory of Discrimination, in Discrimination in Labor Markets, Ashenfelter O. and Rees A. (eds). New Jersey: Princeton University Press.

Arrow, K. J. (1998). What Has Economics to Say about Racial Discrimination? Journal of Economic Perspectives, 12:91-100.

Baldwin, L. M. and William, G. J. (2000). Labor Market Discrimination Against Men With Disabilities in the Year of the ADA. Southern Economic Journal, 66:548-566.

Bayard, K. Hellerstein, J. Neumark, D. and Troske, K. (2003). New Evidence on Sex Segregation and Sex Differences in Wages from Matched Employee-Employer Data. Journal of Labor Economics, 21:887-922.

Baumle, K. A. and Fossett, M. (2005). Statistical Discrimination in Employment. Its Practice, Conceptualization, and Implications for Public Policy. American Behavioral Scientists, 48: $1250-1274$ 
Becker, G. S. (1957). The Economics of Discrimination. Chicago: University of Chicago Press.

Becker, G. S. (1975). Human Capital, 2nd ed. Chicago: University of Chicago Press.

Becker, G. S. (1981). A Treatise on the Family. Cambridge, Massachusetts: Harvard University Press.

Becker, G. S. (1993). Nobel Lecture: The Economic Way of Looking at Behavior. Journal of Political Economy: 385-409.

Bergmann, B. (1971). The Effect on White Incomes of Discrimination in Employment. Journal of Political Economy, 79:294-313.

Bergmann, B. (1974). Occupational Segregation, Wage, and Profits when Employers Discriminate by Race and Sex. Eastern Economic Journal, 1:103-10.

Bergmann, B. (1986). The Economic of Emergence of Women.

Bergmann, B. (1996). In Defense of Affirmative Action. New York: Basic Books.

Bertrand, M. and Mullainathan, S. (2004). Are Emily and Greg More Employable than Lakisha and Jamal? Field Experiment on Labor Discrimination. American Economic Review, 94:991-1014. 
Blau, F. D. Ferber, M. A. Winkler, A. E. (2006). The Economics of Women, Men and Work, $5^{\text {th }}$ Edition. New Jersey: Prentice-Hall, Englewood Cliffs.

Blinder, A. S. (1973). Wage Discrimination: Reduced Form and Structural Estimates. Journal of Human Resources, 8:436-455.

Bogdanic, A. (2005). The Croatian National Program for the Roma: An Example of Gender Inequality. Hungary: European Union Monitoring and Advocacy Program.

Bourne, L. S. (1976). Urban Structure and Land Use Decisions. Annals of the Association of American Geographers, 66:531-541.

Brue, S. L. Macpherson, D. A. and McConnell, C. R. (2006). Contemporary Labor Economics. NewYork: McGraw-Hill/Irwin.

Burstein, P. (1990). Intergroup Conflict, Law, and the Concept of Labor Market Discrimination. Sociological Forum, 5:459-476.

Carlsson, M. and Rooth, D. O. (2007). Evidence of Ethnic Discrimination in the Swedish Labor Market Using Experimental Data. Labor Economics, 14:716-729.

Catanzarite, L. (2000). Brown-Collar Jobs: Occupational Segregation and Earnings of RecentImmigrant Latinos. Sociological Perspectives, 43:45-75. 
Cunningham, S. J. and Zalojkar, N. (1992): The Economic Progress of Black Women, 19401980: Occupational Distribution and Relative Wages. Industrial and Labor Relations Review, 45:540-55.

Davis. D. D. (1987). Maximal Quality Selection and Discrimination in Employment. Journal of Economic Behavior and Organization, 8:97-112.

Directorate-General for Employment, Social Affairs and Equal Opportunities. (2008). Ethnic Minority and Roma Women in Europe: A Case for Gender Equality? Brussels: European Commission.

Dickinson, D. L. and Oaxaca, R. L. (2009). Statistical Discrimination in Labor Markets: An Experimental Analysis. Southern Economic Journal, 76:16-31.

Drydakis, N. (2009). Sexual Orientation Discrimination in the Labor Market. Labor Economics, 16: 364-372.

Drydakis, N. (2010a). Health-Impairments and Labor Market Outcomes. European Journal of Health Economics, 11:457-469.

Drydakis, N. (2010b). Labor Discrimination as a Symptom of HIV: Experimental Evaluation the Greek Case. Journal of Industrial Relations, 52:201-217.

Drydakis, N. (2010c). Religious Affiliation and Labor Bias. Journal for the Scientific Study of Religion, 49: 472-488. 
Drydakis, N. (2010d). Ethnic Discrimination in the Greek Housing Market. Journal of Population Economics, doi: 10.1007/s00148-010-0313-0.

Drydakis, N. (2010e). Ethnic Differences in Housing Opportunities. Urban Studies, 47: 25732596.

Drydakis, N. and Vlassis, M. (2010). Ethnic Discrimination in the Greek Labor Market: Occupational Access, Insurance Coverage, and Wage Offers. Manchester School, 78:201-218.

Drydakis, N. (2011a). Women’s Sexual Orientation and Labor Market Outcomes in Greece. Feminist Economics, 11:89-117.

Drydakis, N. (2011b). Sexual Orientation and Labor Relations: New Evidence from Athens Greece. Applied Economics, forthcoming.

Duncan, O. D. and Duncan, B. (1955). A Methodological Analysis of Segregation Indices. American Journal of Sociological Review, 20:210-17.

England, P. (1994). Neoclassical Economists' Theories of Discrimination, in Burstein, P., (ed.), Equal Employment Opportunity: Labor Market Discrimination and Public Policy. NewYork: Walter de Gruyter.

Eurofound. (2010). Addressing the Gender Pay Gap: Government and Social Partner Actions. European Foundation for the Improvement of Living and Working Conditions. Dublin. 
European Commission. (2008). Ethnic Minority and Roma Women in Europe. A Case of Gender Equality? Luxembourg.

European Roma Rights Center. (2005). Stigmata: Segregated Schooling of Roma in Central and Eastern Europe, a Survey of Patterns of Segregated Education of Roma in Bulgaria, the Czech Republic, Hungary, Romania, and Slovakia. Budapest.

European Roma Rights Centre. (2007). The Glass Box: Exclusion of Roma from Employment. Budapest.

European Monitoring Centre on Racism and Xenophobia. (2006). Roma and Travelers in Public Education; An Overview of the Situation in the European Member States. Vienna.

European Parliament. (2006). Economic Aspects of the Condition of Roma Women. Brussels.

European Roma Rights Center and Greek Helsinki Monitor. (2003). Clearing Operators. Excluding Roma in Greece. Country Report Series, No. 12. Budapest.

European Union Agency for Fundamental Rights. (2009). Data in Focus Report: The Roma. Budapest.

European Women's Lobby. (1999). Overcoming Discrimination, Selected Strategies Empowering Black, Ethnic Minorities and Migrant Women. Brussels. 
Exarchos, G. (1998). Social Exclusion of Roma, in Kassimati, K., (eds), Social Exclusion: The Greek Experience. Athens: Gutenberg.

Groshen, E. (1991). The Structure of the Female/Male Differential: Is It Who you Are, What you Do, or Where you Work? Journal of Human Resources, 26:457-72.

Heckman, J. J. Stixrud, J. and Urzua, S. (2006). The Effects of Cognitive and Noncognitive Abilities on Labor Market Outcomes and Social Behavior. Journal of Labor Economics, 24: 411-82.

Higginis, N. (2010). It's Not That I Am a Racist, it's That They Are Roma; Roma Discrimination and Returns to Education in South-Eastern Europe. International Journal of Manpower, 3:163-87.

Hunt, Y. (1993). Gypsies in Greece, an Annotated Bibliography: Modern Greek Society. A Social Science Newsletter, 21:2-62.

International Labour Office (2007). Eliminating Discrimination Against Indigenous and Tribal Peoples in Employment and Occupation. A Guide to ILO Convention No. 111. Geneva.

Jaret, C. (1995). Contemporary Racial and Ethnic Relations. New York: Harper Collins.

Karathanassi, E. (2000). Roma Life: The Bio and Socio Space of Roma. Athens: Gutenberg. 
Jones, A. (1998). Migration, Ethnicity and Conflict: Oxfam's Experience of Working with Roma Communities in Tuzla, Bosnia-Herzegovina. Gender and Development, 6:57-62.

Komis, K. (1998). Gypsies: History, Demography, Culture. Athens: Ellinika Grammata.

Kozaitis, K. (1997). Foreigners Among Foreigners, Social Organization among the Roma of Athens, Greece. Urban Anthropology, 26:165-99.

Kozaitis, K. (2002). Embrace of Shelter: Cultural Hybridism Among the Roma of Athens, Greece. Ethnologia. Ethnological Society of Greece. Athens.

Lewis, D. (1996). Occupational Crowding. Economic Record, 72:107-117

Logan, J. R. and Molotch, H. L. (1987). Urban Fortunes. The Political Economy of Place. Berkeley: University of California Press.

Macpherson, D. A. and Hirsch, B. T. (1995). Wages and Gender Composition: Why do Women’s Jobs Pay Less? Journal of Labor Economics, 13:426-71.

Makkonen, T. (2007). European Handbook on Equality Data. Belgium: European Communities.

Marantzidis, N. Raptis, N. and Mavrommatis, G. (1999). Traditional Cleintage Relations in Three Communities of Greek Gypsies. Journal of the Gypsy Lore Society, 9:55-70. 
Mincer, J. (1974). Schooling, Experience, and Earnings. New York: National Bureau of Economic Research.

Neumark, D. (1999). Wage Differentials by Race and Sex: The Roles of Taste Discrimination and Labor Market Information. Industrial Relations, 38:414-45.

Oaxaca, R. (1973). Male-Female Wage Differentials in Urban Labor Markets. International Economic Review, 14:693-709.

Okin, M. S. (1997). Is Multiculturalism Bad for Women, in Cohen, J. Howard, M. and Nussbaum, M. (eds). New Jersey: Princeton University Press.

Pager, D. D. and Karafin, D. (2009). Bayesian Bigot? Statistical Discrimination, Stereotypes, and Employer Decision Making. ANNALS of the American Academy of Political and Social Science, 621: 70-193.

Papapetrou, E. (2007). Education, Labor Market and Wage Differentials in Greece. Bank of Greece, Economic Bulletin, 28:51-73.

Pavlou, M. Lykovardi, K. Hormovitis, D. and Prokopi, I. (2009). Housing Conditions of Roma in Greece. Vicious Circles and Consolidated Rights. Athens: National Focal Point on Racism and Xenophobia and, Institute for Rights, Equality and Diversity.

Petit, P. (2007). The Effect of Age and Family Constraints on Gender Hiring Discrimination: a Field Experiment in the French Financial Sector. Labor Economics, 14:371-391. 
Pinkston, J. (2003). Screening Discrimination and the Determinants of Wages. Labor Economics, 10:643-658.

Portes, A. and Sensenbrenner, J. (1993). Embeddedness and Immigration. Notes on the Social Determinants of Economic Action. American Journal of Sociology, 98:1320-1350.

Ratcliffe, P. (1998). Race Housing and Social Exclusion. Housing Studies, 13:807-18.

Riach, P. A. and Rich, J. (1991). Testing for Racial Discrimination in the Labor Market. Cambridge Journal of Economics, 15: 239-256.

Riach, P. A. and Rich, J. (1995). An Investigation of Gender Discrimination in Labor Hiring. Eastern Economic Journal, 21:343-356.

ROM Network. (2000). Pan-Hellenic Census Study Investigating the Social, Housing Conditions and Needs of Greek Roma Citizens. Athens.

Schelling, T. C. (1969). Models of Segregation. American Economic Review, 59:488-493.

Simón, H. Sanromá, E. and Ramos, R. (2008). Labor Segregation and Immigrant and NativeBorn Wage Distributions in Spain: An Analysis Using Matched Employer-Employee Data. Spanish Economic Review, 10:2135-2168

Stewart, M. (1997). The Time of the Gypsies. Oxford: Westview Press. 
Swinton, D. H. A. (1977). Labor Force Competition Theory of Discrimination in the Labor Market. American Economic Review, 67:400-404.

Tickamyer, A. R. (2000). Space Matters! Spatial Inequality in Future Sociology. Contemporary Sociology, 29:850-13.

Unite Nation Committee on the Elimination of Discrimination Against Women. (2002). Violence and Women in Greece. New York.

Vaxevanoglou, A. (2001). Greek Gypsies: Marginalized and Family Men. Athens: Alexandreia.

Weichselbaumer, D. (2003). Sexual Orientation Discrimination in Hiring. Labor Economics, 10:629-642.

Wilson, A. (2001). Complex Spatial Systems: The Modelling Foundation of Urban and Regional Analysis. United Kingdom: Pearson Education. 
Table 1. Descriptive Statistics: Non-Roma and Roma Women

\begin{tabular}{|c|c|c|}
\hline & Non-Roma Women & Roma Women \\
\hline Number of Observations & 4,679 & 961 \\
\hline Mean hourly wages (natural log) & 3.50 & 3.12 \\
\hline - white-collar jobs & 3.53 & 3.21 \\
\hline - blue collar jobs & 3.42 & 3.04 \\
\hline - service jobs & 3.47 & 3.10 \\
\hline -public jobs & 3.55 & 3.21 \\
\hline -private jobs & 3.46 & 3.08 \\
\hline Mean age & 35.89 & 33.36 \\
\hline Percentage who are married & $65.98 \%$ & $84.49 \%$ \\
\hline Mean number of children in household & 0.87 & 1.43 \\
\hline Percentage with health limitations & $6.90 \%$ & $4.34 \%$ \\
\hline $\begin{array}{l}\text { Percentage completing minimum } \\
\text { mandatory education }\end{array}$ & $96.37 \%$ & $45.99 \%$ \\
\hline Percentage of high school graduates & $86.18 \%$ & $18.41 \%$ \\
\hline $\begin{array}{l}\text { Percentage of university or technical } \\
\text { school graduates }\end{array}$ & $47.20 \%$ & $9.57 \%$ \\
\hline Percentage with computing skills & $65.24 \%$ & $7.49 \%$ \\
\hline Percentage with English skills & $47.30 \%$ & $7.38 \%$ \\
\hline Percentage with driving license & $58.91 \%$ & $5.29 \%$ \\
\hline Mean years of experience & 12.96 & 16.11 \\
\hline Percentage in white-collar jobs & $40.63 \%$ & $5.51 \%$ \\
\hline Percentage in blue-collar jobs & $46.52 \%$ & $88.78 \%$ \\
\hline Percentage in service occupations & $12.58 \%$ & $5.54 \%$ \\
\hline Percentage in public sector & $43.97 \%$ & $13.14 \%$ \\
\hline Percentage in private sector & $55.99 \%$ & $86.75 \%$ \\
\hline $\begin{array}{l}\text { Percentage employed in the area of } \\
\text { residence }\end{array}$ & $36.48 \%$ & $45.05 \%$ \\
\hline Percentage living in Agia Varvara & $7.02 \%$ & $7.14 \%$ \\
\hline Percentage living in Agioi Anargyroi & $6.54 \%$ & $5.82 \%$ \\
\hline Percentage living in Aigaleo & $4.52 \%$ & $9.91 \%$ \\
\hline Percentage living in Ano Liosia & $8.24 \%$ & $4.18 \%$ \\
\hline Percentage living in Aspropyrgos & $4.15 \%$ & $7.70 \%$ \\
\hline Percentage living in Eleusina & $3.92 \%$ & $8.27 \%$ \\
\hline Percentage living in Zefyri & $6.52 \%$ & $2.99 \%$ \\
\hline Percentage living in Ilion & $6.67 \%$ & $2.11 \%$ \\
\hline Percentage living in Kamatero & $7.23 \%$ & $3.09 \%$ \\
\hline Percentage living in Keratsini & $5.11 \%$ & $12.02 \%$ \\
\hline Percentage living in Korydallos & $5.23 \%$ & $7.71 \%$ \\
\hline Percentage living in Menidi & $4.60 \%$ & $8.08 \%$ \\
\hline Percentage living in Nikaia & $5.57 \%$ & $5.38 \%$ \\
\hline Percentage living in Perama & $5.13 \%$ & $5.14 \%$ \\
\hline Percentage living in Petroupoli & $7.81 \%$ & $6.70 \%$ \\
\hline Percentage living in Xaidari & $11.74 \%$ & $3.76 \%$ \\
\hline
\end{tabular}




\section{Table 2. Extent of Occupational Segregation}

\section{Occupations}

- white-collars jobs

- blue-collars jobs

0.21

- service jobs

Total

\section{Sectors}

- public jobs

- private jobs

Total

Notes: The extent of occupational segregation is measured by $S_{i}=\frac{1}{2} \sum_{i=1}^{W}(N R-R)$, where $S_{i}$ is the index of occupational segregation, $N R$ is the percentage of the non-Roma employed in the $i^{\text {th }}$ occupation/sector, $R$ is the percentage of the Roma worker employed in the $i^{\text {th }}$ occupation/sector and $N$ is the number of occupations/sectors. Values of the index that are closer to zero correspond to more equal jobs distributions. 


\section{Table 3. Measurement of Occupational Crowding}

\section{Occupations}

-non-Roma workers

0.72

-Roma workers

\section{Sectors}

- non-Roma workers

-Roma workers

Notes: The coefficient of variation is measured by $=\frac{\sqrt{\Sigma}\left[x_{i}-\mu y^{2} / N\right.}{\sum_{i=1}^{N} x_{i}^{\prime} / N}$, where CV is the coefficient of variation, $\mu$ is the mean, $X_{i}$ is the number of non-Roma or Roma in the $i^{\text {th }}$ occupation/sector, $N$ is the number of occupations/sectors. Larger values of CV indicate higher levels of occupational crowding. CV will equal zero if there is no occupational crowding. 
Table 4. Wage Estimations

\begin{tabular}{lll}
\hline & Non-Roma & Roma \\
Age & & \\
Marital status & $0.065(0.007)^{*}$ & $0.059(0.011)^{*}$ \\
Health status & $0.020(0.008)^{*}$ & $0.026(0.011)^{*}$ \\
Children & $-0.045(0.012)^{*}$ & $-0.041(0.020)^{*}$ \\
Actual working experience & $0.012(0.004)^{*}$ & $0.009(0.003)^{*}$ \\
White-collar jobs & $0.028(0.007)^{*}$ & $0.021(0.002)^{*}$ \\
Blue-collar jobs & $0.024(0.009)^{*}$ & $0.018(0.004)^{*}$ \\
Public jobs & $0.019(0.013)$ & $0.011(0.008)$ \\
Workplace in the area of residence & $0.023(0.009)^{*}$ & $0.019(0.007)^{*}$ \\
Minimum mandatory education & $0.012(0.009)$ & $0.011(0.016)$ \\
Graduation from high school & $0.028(0.009)^{*}$ & $0.017(0.006)^{*}$ \\
University or technical school diploma & $0.033(0.012)^{*}$ & $0.020(0.007)^{*}$ \\
Computer knowledge & $0.038(0.008)^{*}$ & $0.023(0.010)^{*}$ \\
English knowledge & $0.002(0.007)$ & $0.012(0.034)$ \\
Driving license & $0.009(0.011)$ & $0.013(0.016)$ \\
Location controls & $0.002(0.007)$ & $0.005(0.021)$ \\
Intercept & Yes & Yes \\
R & $1.572(0.054)^{*}$ & $1.206(0.140)^{*}$ \\
Observations & 0.622 & 0.683 \\
\hline
\end{tabular}

Notes: We use the method of Ordinary Least Squares to compute the estimations. Standard errors are in parenthesis. *Significant at the $1 \%$ level. 
Table 5. Roma and non-Roma Wage Decomposition; Entire Sample

\begin{tabular}{|c|c|c|c|c|}
\hline & Coefficients & $\begin{array}{c}\text { Robust Standard } \\
\text { Errors }\end{array}$ & Coefficients & $\begin{array}{c}\text { Robust Standard } \\
\text { Errors }\end{array}$ \\
\hline Occupation Dummies & YES & & NO & \\
\hline Sector Dummies & YES & & NO & \\
\hline \multicolumn{5}{|l|}{ Panel A } \\
\hline Mean prediction non-Roma & 3.501 & $0.034 *$ & 3.501 & $0.034 *$ \\
\hline Mean prediction Roma & 3.129 & $0.057^{*}$ & 3.129 & $0.057 *$ \\
\hline Raw differential & 0.372 & $0.111 *$ & 0.372 & $0.111^{*}$ \\
\hline \multicolumn{5}{|l|}{ Panel B } \\
\hline Due to endowments & 0.126 & $0.056^{*}$ & 0.121 & $0.056^{*}$ \\
\hline Due to coefficients & 0.246 & $0.040 *$ & 0.251 & $0.018 *$ \\
\hline \multicolumn{5}{|l|}{ Panel C } \\
\hline Explained & 0.338 & $0.068^{*}$ & 0.325 & $0.043^{*}$ \\
\hline Unexplained & 0.662 & $0.024 *$ & 0.675 & $0.027 *$ \\
\hline
\end{tabular}

Notes: We use the Oaxaca-Blinder Decomposition technique to compute the estimations. Standard errors are in parenthesis. *Significant at the $1 \%$ level. 
Table 6. Roma and non-Roma Wage Decomposition; Occupation Subgroups

\begin{tabular}{cc}
\hline Coefficients & Robust Standard \\
Errors
\end{tabular}

I. White-Collar Jobs

\section{Panel AI}

Mean prediction non-Roma

3.534

$0.056^{*}$

Mean prediction Roma

3.214

$0.045^{*}$

Raw differential

0.320

$0.079 *$

\section{Panel BI}

Due to endowments

0.138

$0.041^{*}$

Due to coefficients

0.182

$0.048 *$

Panel CI

Explained

0.431

$0.051^{*}$

Unexplained

0.568

$0.084^{*}$

II. Blue-Collar Jobs

\section{Panel AII}

Mean prediction non-Roma

3.420

$0.018^{*}$

Mean prediction Roma

3.040

$0.067^{*}$

Raw differential

0.380

$0.084 *$

Panel BII

Due to endowments

0.087

$0.021 *$

Due to coefficients

0.293

0.096*

Panel CII

Explained

0.228

$0.067 *$

Unexplained

0.771

$0.074 *$

\section{Services Jobs}

\section{Panel AIII}

Mean prediction non-Roma

$0.042 *$

Mean prediction Roma

0.367

$0.054 *$

Raw differential

Panel BIII

Due to endowments

$0.143 \quad 0.049 *$

Due to coefficients

0.224

$0.042 *$

\section{Panel CIII}

\section{Explained}

0.389

$0.076^{*}$

Unexplained

0.611

$0.024 *$

Notes: We use the Oaxaca-Blinder Decomposition technique to compute the estimations. Standard errors are in parenthesis. *Significant at the $1 \%$ level. 
Table 7. Roma and non-Roma Wage Decomposition; Sector Subgroups

Coefficients Robust Standard Errors

I. Public Sector

\section{Panel AI}

Mean prediction non-Roma

3.553

$0.070^{*}$

Mean prediction Roma

3.219

$0.064 *$

Raw differential

0.334

$0.051^{*}$

Panel BI

Due to endowments

0.151

0.059*

Due to coefficients

0.183

$0.048 *$

Panel CI

Explained

0.452

0.074*

Unexplained

0.548

$0.036^{*}$

II. Private Sector

\section{Panel AII}

Mean prediction non-Roma

3.464

$0.041 *$

Mean prediction Roma

3.089

$0.036^{*}$

Raw differential

0.375

$0.054^{*}$

\section{Panel BII}

Due to endowments

0.092

0.052*

Due to coefficients

0.283

$0.072 *$

\section{Panel CII}

Explained

0.245

$0.061 *$

Unexplained

0.754

$0.079 *$

Notes: We use the Oaxaca-Blinder Decomposition technique to compute the estimations. Standard errors are in parenthesis. *Significant at the $1 \%$ level. 
Table 8. Roma and non-Roma Wage Decomposition; Education Subgroups

\author{
Coefficients
}

Robust Standard Errors

I. Minimum Mandatory Education

\title{
Panel AI
}

Mean prediction non-Roma

$\begin{array}{ll}3.396 & 0.038^{*} \\ 3.088 & 0.045^{*} \\ 0.308 & 0.064^{*} \\ & \\ 0.096 & 0.023^{*} \\ 0.212 & 0.056^{*} \\ & \\ 0.311 & 0.067^{*} \\ 0.689 & 0.084^{*}\end{array}$

Mean prediction Roma

Raw differential

Panel BI

Due to endowments

Due to coefficients

Panel CI

Explained

Unexplained

0.689

$0.084^{*}$

II. High School Graduates

\section{Panel AII}

Mean prediction non-Roma

$0.051^{*}$

Mean prediction Roma

3.214

$0.101^{*}$

Raw differential

0.276

0.053*

Panel BII

Due to endowments

0.097

$0.037 *$

Due to coefficients

0.179

$0.022 *$

Panel CII

Explained

0.351

$0.101^{*}$

Unexplained

0.648

$0.089 *$

III. University or a Technical School Diploma

\section{Panel AIII}

Mean prediction non-Roma

$3.614 \quad 0.045^{*}$

Mean prediction Roma

3.424

$0.037 *$

Raw differential

0.190

$0.042 *$

Panel BIII

Due to endowments

$0.0750 .019 *$

Due to coefficients

0.115

$0.032 *$

\section{Panel CIII}

Explained

0.394

$0.109^{*}$

Unexplained

0.605

$0.056^{*}$

Notes: We use the Oaxaca-Blinder Decomposition technique to compute the estimations. Standard errors are in parenthesis. *Significant at the $1 \%$ level. 


\section{Appendix}

\section{Definitions of Variables}

\begin{tabular}{|c|c|}
\hline Variable Name & Definition \\
\hline NLHN & Natural logarithm of hourly wages \\
\hline ROMA & 1 if individual has a Roma origin; 0 otherwise \\
\hline AGE & Years of age \\
\hline MARR & 1 if individual is married; 0 otherwise \\
\hline CHIL & The number of the surveyed individual's children \\
\hline DIS & $\begin{array}{l}1 \text { if individual is limited in kind or amount of work, has a mobility limitation, or has a personal } \\
\text { care limitation; } 0 \text { otherwise }\end{array}$ \\
\hline SCHOL & 1 if individual has completed minimum mandatory education; 0 otherwise \\
\hline GRAD & 1 if individual has graduated from a high school; 0 otherwise \\
\hline UNIV & 1 if individual has university or a technical school diploma ; 0 otherwise \\
\hline CS & 1 if individual has computer skills; 0 otherwise \\
\hline ENGL & 1 if individual has knowledge of English; 0 otherwise \\
\hline DRIV & 1 if individual has a driving license; 0 otherwise \\
\hline EXPER & Years of actual working experience \\
\hline WHITE & $\begin{array}{l}1 \text { if individual's occupation is among managerial or professional specialties, or the individual } \\
\text { works in a technical, sales, or administrative support position; } 0 \text { if individual is in service } \\
\text { occupation (SERV) i.e. food preparation, protective service occupation, ground cleaning and } \\
\text { maintenance occupations, personal care and healthcare support occupations }\end{array}$ \\
\hline BLUE & $\begin{array}{l}1 \text { if individual's occupation is among precision production, craft, or repair occupations, or the } \\
\text { individuals works as an operator, fabricator or laborer; } 0 \text { if individual is in service occupation } \\
\text { (SERV) }\end{array}$ \\
\hline PUBL & 1 if individual is employed in the public sector; 0 if individual is in private sector (PRIV) \\
\hline INSI & 1 if individual's work is in the same municipality as her residence; 0 otherwise \\
\hline MUN_1 & 1 if individual’s household located in Agia Barbara; 0 reference group (Xaidari) \\
\hline MUN_2 & 1 if individual's household located in Agioi Anargyroi; 0 reference group (Xaidari) \\
\hline MUN_3 & 1 if individual's household located in Aigaleo; 0 reference group (Xaidari) \\
\hline MUN_4 & 1 if individual's household located in Ano Liosia; 0 reference group (Xaidari) \\
\hline MUN_5 & 1 if individual's household located in Aspropyrgos; 0 reference group (Xaidari) \\
\hline MUN_6 & 1 if individual's household located in Eleusina; 0 reference group (Xaidari) \\
\hline MUN_7 & 1 if individual's household located in Zefyri; 0 reference group (Xaidari) \\
\hline MUN_8 & 1 if individual's household located in Ilion; 0 reference group (Xaidari) \\
\hline MUN_9 & 1 if individual's household located in Kamatero; 0 reference group (Xaidari) \\
\hline MUN_10 & 1 if individual's household located in Keratsini; 0 reference group (Xaidari) \\
\hline MUN_11 & 1 if individual's household located in Korydallos; 0 reference group (Xaidari) \\
\hline MUN_12 & 1 if individual's household located in Menidi; 0 reference group (Xaidari) \\
\hline MUN_13 & 1 if individual's household located in Nikaia; 0 reference group (Xaidari) \\
\hline MUN_14 & 1 if individual's household located in Perama; 0 reference group (Xaidari) \\
\hline MUN_15 & 1 if individual’s household located in Petroupoli; 0 reference group (Xaidari) \\
\hline
\end{tabular}

